\title{
Production, labour market and working life
}

\author{
Niels Jul Nielsen
}

There is general agreement that the contemporary economy and labour is volatile, unpredictable, fluid, temporary and precarious. In order to describe this overall change, there are manifold notions of labour and production within scholarly discourse. To mention just a few: 'corrosion of character', 'precarity', eroding 'work/family balance', ' 'platform economy', 'knowing capitalism', 'transnationalism', 'liquid modernity ${ }^{9}$. Many scholars hold that on an individual level former social relationships and hierarchies are destabilised, that demarcations of leisure and work are blurred, and that life courses become increasingly unpredictable. While it is correct that the changes that contemporary societies are undergoing are grave, similar transformations of the social and economic landscape have also occurred before in cultural history.

Danish ethnology - similar to most Scandinavian and Central European ethnology has a long tradition of inquiring into society's basic means of subsistence, i.e. its material and economic conditions, and understands this in relationship to social architecture. Society has been understood as being made up of different groups of citizens whose ways of life are both in contrast to each other as well as connected through ties related to production and labour. Ethnologists have studied 18th and 19th century societies through groups such as tenant farmers, smallholders, artisans, traders, nobility and civil servants in this way. Likewise, in the 20th century, the focus has been placed on self-employed farmers, blue- and white-collar workers, stay-at-home housewives, manufacturers and public servants among others ${ }^{7}$. Such groups have been understood

SENNETT, RICHARD: The culture of the new capitalism. New Haven 2006.

2 BOURDIEU, PIÈRRE: Firing back. Against the tyranny of the market. New York/London 2006. - STANDING, GUY: The precariat, the new dangerous class. London 2011.

3 HOCHSCHILD, ARLIE R.: The time bind. When work becomes home and home becomes work. New York 1997.

4 ThrifT, NigEL J.: Knowing capitalism. London 2005.

5 Schiller, Nina G./ BASCH, Linda G./ SzAnTON BlanC, Cristina (Eds.): Towards a transnational perspective on migration: race, class, ethnicity, and nationalism reconsidered. New York 1992. - WIMMER, ANDREAS/ SCHILLER, NINA G.: Methodological nationalism and beyond: nation-state building, migration and the social sciences. Global Networks (2002), Vol. 2 (4), p. 301-334.

BAUMAN, ZYGMUNT: Liquid modernity. Cambridge 2000.

7 BUUS, HENRIETTE: Sundhedsplejerskeinstitutionens dannelse: en interpellationsanalyse. København 1999. - CHRISTIANSEN, PALlE O.: En livsform på tvangsauktion?: en bog om landbrug og mennesker i dagens Danmark. København 1983. - ID.: A manorial world: lord, peasants and cultural distinctions on a Danish estate, 1750-1980. Oslo 1996. - DAMSHOLT, TINE: Fædrelandskærlighed og borgerdyd. Patriotisk diskurs og militære reformer i Danmark i sidste del af 1700-tallet. København 2000. - HøJRUP, THOMAS: Det glemte folk: livsformer og centraldirigering. Hørsholm 1983. - JUL NIELSEN, NIELS: Virksomhed og arbejderliv. Bånd, brudflader og bevidsthed på B\&W 1850-1920 [Enterprise and Workers' Life: Bonds, Ruptures and Consciousness on B\&W 1850-1920]. Copenhagen 2002. - ID.: Mellem storpolitik 
as distinct from each other, yet co-existing in interdependency in some form of a whole, be it of a national or transnational kind. Present studies within Danish ethnology, evolving from and further developing the so-called state and life-mode theory, endeavour to comprehend the significant transformations and characteristics of contemporary production and working cultures along these same lines. How can different forms of social lives even today be understood as enduring; how do they make sure that the means for their continuance are repetitively reproduced? This calls for maintaining focus on the mutual relationship between social practices and the different means of organising of production. Some life-modes seem to be gravely challenged or are maybe disappearing, while others are flourishing or entering the social whole - followed by new forms of contradictions and connections.

In the following, a brief sketch of a few of the interpretations of significant historical transformations of production and working practices will first be made, followed by a discussion of how to comprehend the complexity of contemporary capitalism in relation to practices of work. Building upon this, such practices are exemplified in micro perspective through an analytical sketch, taken from an ongoing research project, of the recent history of one particular Danish company and (what can be seen as) its connected life-modes.

\section{Cultural historic transformations}

Throughout history the relationship both within and between different social groups has continuously undergone alterations. State and life-mode theory draws on the classical notion of praxis (as elaborated in particular by ARISTOTLE, HEGEL and MARX): a subject's purposeful intervention towards an object viewed as part of an inanimate nature $^{8}$. From this basis both the concepts of modes of production and their interrelated life-modes have been developed into a self-determined conceptual hierarchy, as pointed out in the introductory article'. Life-modes and modes of production constitute each other and are merely two different ways of specifying the concept of praxis: as work and as production ${ }^{10}$. Key to the approach, moreover, is that such relations are not sufficiently understood - and thus useful for cultural historic inquiries - without establishing them as components of some sort of survival units, i. e. as parts of societies under-

og værkstedsgulv: den danske arbejder : før, under og efter den kolde krig [Between High Politics and the Workshop Floor. The Danish Worker - Before, During and After the cold War]. Copenhagen 2004. - MøllgaARD, Eske J.: Skive 1660-1800. In: Gormsen G./ Mortensen N. (Eds.): Skive kommunes historie. 2001. - STOKLUND, BJARNE: Læsø land : økologi og kultur i et øsamfund 1550-1900. Vols. 1-2. Copenhagen 2018.

8 Boserup, ANDERS: Staten, samfundet og krigen hos Clausewitz. In: Om Krig. bd. III: Kommentar og registre. København 1986, p. 920.

9 Cf. DAMShOLT/ MEllemgaARD: Ruptures and Reorientations, in this volume.

10 HøJRUP, ThOMAS: State, culture, and life-modes. The foundations of life-mode analysis. Aldershot 2003, p. $106 \mathrm{ff}$. 
stood to be enduring. This implies a concept of state $^{11}$. The reasoning is that life-modes and modes of production depend on specific conditions for their endurance. Such conditions require a subject of a higher order, a survival unit, to be safeguarded. If the struggle for survival and recognition should not have to be enacted in every intersubjective relationship, it must be subjugated to a superior subject. Accordingly, a basic distinction between dependent subjects (on the life-mode level: citizens, companies, corporations etc.) and a self-defending subject is set out. The latter, usually identified as a state (but empirically ranging from the horde to complex modern and not easily demarcatable states) builds up sufficient defensive capability to prevent other states from approaching it as inanimate nature. Understood in this way states are always involved in a necessary struggle for external recognition, and internally strive through sovereignty work to build up sufficient strength to remain independent wills in the world. For instance, by providing necessary conditions for particular modes of production and social lives and working practices; that is, by recognizing the practices required for its endurance ${ }^{12}$. Cultural history is a continuous struggle of what can be comprehended as dependent subjects fighting for maintaining and improving the conditions for their praxis vis-à-vis state-subjects that struggle for their endurance in the world by upholding sufficient defence capability. The unceasing adjustments evolving from such processes eventually lead to fundamental cultural historic transformations.

Two historical examples can be illustrative for these processes: One form of the simple commodity mode of production (characterized by direct producers' control over the entire labour process and they themselves extracting the end product) were the master guilds, which originated in the Middle Ages. These were based on staterecognized monopolized markets for labour (such as regulation of supply of journeymen and fixed wages), goods (such as fixed prices and distribution of raw materials) and service providers (regulation of the number of production entities). Steadily, from the end of the $18^{\text {th }}$ century - due to struggles between different interests among producers as well as journeymen's increasing difficulties reaching the status of masterthese restrictions were lifted and eventually lead to the Act on Freedom of Trade in 1857. This paved the way for a transformation from the monopoly-based form of simple commodity mode of production to a liberal free-market form. A similar change was the agricultural reforms that took off in the late $18^{\text {th }}$ century in Danish society. The reforms marked a transformation in the mode of production, in this case from a material and economic organization based on what can be theoretically understood as the feudal mode of production (large landowners and peasants with copyhold tenure) to a specific form of simple commodity mode of production: freeholding peasants who came to

11 Bosereup (cf. note 8). - HøjRup (cf. note 10). - KASPERSEN, LARS B./ GABriel, Norman: Survival units as the point of departure for a relational social theory. 2005.

12 Importantly, basing the thinking on the German war theorist C. V. CLAUSEWITZ (1780-1831) and his theorem of the defensive as a more efficient form of warfare than the offensive (other things being equal), it is the developing of sufficient defense capability that is understood as constituting a process of state-building, and not, as is often assumed, offensive warfare. For a thorough elaboration of the conceptual hierarchy, and the ways of continuously working to improve it (cf. HøJRUP, note 10). 
form the basis for what over the subsequent century developed into the influential Danish family farmers.

When relations and transformations of production and work are to be explained, the interrelationships between what can theoretically be grasped as state and life-modes as well as between life-modes are indeed complex and not a matter of either a top-down or a bottom-up explanation. This is despite the asymmetry of the theory: no life-mode or mode of production can endure without the recognition of the state that ultimately conditions it, whereas a state does not necessarily need all its life-modes and modes of production to survive. The agricultural reforms of the late 18th century - although celebrated at the time as the emancipation of the peasantry - should be understood first and foremost as having been initiated and implemented 'from above'. They were a means to increase rural production output, they were a way of subjectifying peasants to be citizens with a will to defend the state, and they were a measure with which the rising, yet politically restricted, bourgeoisie could promote a liberal agenda ${ }^{13}$.

In sharp contrast to this was the case a hundred years later as workers claimed their right for collective representation vis-à-vis both capitalists and politicians. This developed into an equally fundamental transformation, but one that was far from a top-down initiative $^{14}$. Actually, authorities initially used all available means to suppress the dawning consciousness of labour as a collective subject; they relied entirely on the liberal understanding of the market as appropriate for handling labour-employer relations in the new liberal and capitalistic era. Eventually, though, by the end of the $19^{\text {th }}$ century the irresistible mobilisation of workers led to the state's recognition of workers' collective representation as a formal counterpart to employers. The belief matured among the authorities that an organised labour market system in return warranted the support of the labour movement for the basic pillars of the liberal constitution and the capitalist economic system. Thus, in this conflict-ridden process workers were eventually provided with the right to monopolise the supply of work and thereby acquired influence on wage and working conditions, a transformation that also happened in other European countries as a way of formalising the regulation of conflicting interests ${ }^{15}$. In Denmark a specific variety evolved, with the labour and employer organisations laying out the conditions on the labour market relatively autonomously (later referred to as The Danish Model). With the evolution of the welfare state and the high level of social security this later became known as flexicurity, where employment ties are flexible (enabling easy hiring and firing) combined with a relatively high level of unemployment benefits and vocational training to facilitate re-employment ${ }^{16}$. The examples illustrate

13 DAMSHOLT (cf. note 7). - HOLMGAARD, JENS: Landboreformer - drivkræfter og motiver. Fortid og Nutid (1977), p. 37-47. - LøGSTRUP, BIRGIT: Den danske vej til moderniteten. Temp - tidsskrift for historie (2016), Vol. 6 (12), pp. 59-73.

14 JUL NIELSEN, 2002 (cf. note 7).

15 HYMAN, RICHARD: Understanding European trade unionism between market, class and society. London 2001.

16 Jul OlSEN, Janus/ Jul NiELSEN, NiEls: Flexicurity without Security. An Inquiry into the Danish Flexicurity Model in a Neoliberal Era. In: Ethnologia Europaea 47 (2017), issue 2, pp. 40-56. 
that a proper understanding of transformation (as well as endurance) on state level requires an understanding of existential matters on life-mode level - and vice versa.

Seen in the light of the grave post-1990 changes, the main part of $20^{\text {th }}$ century can be regarded as a phase of stabilisation of labour markets and production relations; although the period obviously also was marked recurrently by struggles between different kinds of life-mode interests. Generally though, labour interests were protected, and though both large and small scale businesses were imperilled by changing market conditions ${ }^{17}$ the Danish market was still relatively protected within the prevalent Keynesian political framework.

\section{Contemporary capitalism}

In the regime of post-1990 neoliberal political economy competition has risen to a new level, as mirrored by the concepts referred to at the beginning of this article. This is especially a consequence of the marketisation of former planned economies as well as a - connected - spread of liberal trade agreements such as the WTO that expose every nation's economy to potential world-wide competition. It appears clear that the reasons behind a philosophy of protecting companies and labour from the forces of the market, which roughly determined the Western political economy well into the 1970s, have lost weight with policymakers discernibly ${ }^{18}$.

As investigated by Danish ethnologists, liberal agendas have also hit businesses hard, that are understandable as simple commodity forms of production. Danish fisheries, following a current in EU fishery politics, were privatized in 2005, a reform that potentially favoured large capitalistic entities based on investor and wage-earner lifemodes at the expense of self-employed small-scale family businesses. This has resulted in countermeasures from the latter in order to maintain living conditions. For instance, they have organized in cooperatives and marketed high-value products, thereby endeavouring to compete with capitalistically organized fishing entities ${ }^{19}$. Danish family farms are still predominantly run by people that arguably should be conceptualized as being an example of the self-employed life-mode. This life-mode implies that the maintenance of the business is not foremost a means to extract a surplus. Rather, all actors involved regard the maintenance a goal in itself, as they all rely on the business' continuance and thus do not require a specific profit to contribute their commitment. Yet, in agriculture there are also political reforms - such as rights to combine ever larger plots of farmland, as well as the right to buy large farm holdings without agri-

17 Sometimes fatally as was the case already in the 1950s with the Danish textile production, which today is almost entirely reduced to area of high value-content design. MELCHIOR, MARIE R.: Dansk på mode! Fortællinger om design, identitet og historie i og omkring dansk modeindustri. Copenhagen 2013.

18 For an elaboration of this argument, see: JUL NIELSEN, 2004 (cf. note 7).

19 HøJRUP, THOMAS/ SCHRIEWER, KLAUS: European fisheries at tipping-point = La pesca europea ante un cambio irreversible. Murcia 2012. - HøST, JEPPE: Market-based fisheries management. Private fish and captains of finance. Cham 2015. 
cultural skills - paving the way for capitalistic organized entities and their connected life-modes ${ }^{20}$.

The capitalist mode of production in its contemporary forms - which, it must be remembered, co-exists with different forms of production better understandable as simple commodity mode of production - is marked by an extreme temporariness and volatility. Nonetheless it is a key research agenda within the strand of state and lifemode theory not to see it as being beyond systemic principles ${ }^{21}$. One research question is to explore whether MARX's basic theorem of profit being based on unpaid work still applies, but can take new forms (such as social media's harvesting of user-data, instead of extracting surplus value from employees $)^{22}$. Another agenda is to comprehend the paradox that capitalistic entities can be extremely powerful (occasionally claimed to exceed the power of states), but only as long as they manage to attract the basic lifemodes of capitalistic business-running: not only wage-earners, but also investors that provide venture capital and career-professionals that supply the expertise that reestablish - again and again - a competitive edge. Thus, since the life-modes connected to the capitalist mode of production all use the production unit merely as a means in their practice (for wages, for profits, for career opportunities) a specific company is constantly subjected to a potential loss of these components if conditions for wages, profits and careers are regarded to be better elsewhere. This volatility appears to have increased significantly in the globalised economy.

\section{Life-mode and state practices}

When characteristics of the contemporary world order - 'global', 'transnational', 'borderless', etc. - are experienced by individual subjects, they appear to be something externally emerging that rip up previous (more) nationally based cultural practices. In analytical terms the task must be to understand such characteristics not as external to the applied theory but within the conceptual framework used when inquires are made. Here is one example of how this is endeavoured within state and life-mode theory: what appears for Danish entrepreneurs to be increasingly harsh competition from 'outside' is analytically understood as other states' reorganisation of their inner landscape of particular modes of production and life-modes, in their striving for strength and recognition in the state system. For example, this occurs when former planned economies become market economies and provide the conditions for capitalist business running, i.e. entrepreneurship and use of wage-earners (with comparably low wages). Thus, when one state - through the internal organisation of its production and social life - employs means to achieve its aim of improving its position in the state system, it

20 BLÆDEL, RASMUS: Vilkår, virkeligheder \& vanskeligheder i dansk landbrug - en etnologisk undersøgelse ( $\mathrm{PhD}$ thesis). University of Copenhagen 2016.

${ }^{21}$ THRIFT (cf. note 4), pp. 4 f.

22 HøJRUP, THOMAS: Rethinking the capitalist mode of production and its life-modes. Working paper. Copenhagen 2017. 
changes the conditions for other states and their material and social base. Likewise, on the level of life-modes, when different life-modes employ means to reach their goals facing ever-changing conditions like the above-mentioned - they change the conditions for other life-modes as will be demonstrated below.

Accordingly, a notion like 'transnationalism' rightfully designates the multiple webs of practices that cut across traditional national borders and are of immense importance for practices of production and work. In state and life-mode terms, though, 'transnationalism' is not comprehended as a renunciation of the concept of the state as a key analytical concept for understanding everyday practices of production and work, since these ultimately are dependent on conditions provided by a 'state' that is able to claim a sovereignty domain. Instead, transnational characteristics are seen as dependent on the state system. Viewed in this way, one must assume that the apparent transnationalism in all probability will be reversed, when it is seen to compromise the sovereignty domain of (sufficiently powerful) states. At present, such a turnaround can be witnessed for instance with the TRUMP administration, which raises tax - and other walls in an attempt to protect the country's production and working practices. This is indeed paradoxical, since the United States traditionally has been the prime promoter of free trade and open borders as a measure to expand its sovereignty domain far beyond its geographical borders. As it is though, today the opposite strategy is considered - by the political actors currently setting the agenda - to be the appropriate way to safeguard the sovereignty domain of the state and its production and work practices. This leads to a process of renationalization, or maybe 'de-transnationalisation' if one like.

Additionally, contemporary cross-border labour migration, which is inseparable from the realms of production and work, is subject to considerable research in Danish ethnology. Across Europe the challenge of labour migration gives rise to agendas that range from interest in the potentials for an increase in productivity to the risk of a rise in xenophobia and right-wing nationalism. Labour migration is not a novel feature, yet it is configured today in forms that would have been unimaginable only half a century ago. In that period migration was subject to strict quota regulations and migrants were incorporated unmitigatedly into influential national unions, at least in Denmark. Today, the influx of foreign workers has a serious impact on already shaken national labour market systems. Thus, what previously - within a Keynesian protectionist regime - was sturdily dammed into national containers, since the 90s has been marked by transnational, border-crossing mobility, and will be until the political strategy, if that is possible, alters again. Danish ethnological investigations have inquired into - particularly - Polish and Ukrainian workers in construction and agriculture and their encounter with the Danish labour market. Key research questions have been: How are foreign workers met by their Danish counterparts? How can mobility be understood as part of the migrants' life-course and family life? How does the organised system of unions and employers' organisations grasp the challenge of incoming labour? Can the re- 
nowned Danish flexicurity model prevent fractures that eventually result in social dissolution $^{23}$ ?

\section{Contemporary transformations of production and the relations of working life: an example}

Processes of complex transformations of relations between both states and life-modes, like the ones sketched above, are termed neo-culturation in state and life-mode theory. In the following, a current example of research in neoculturation processes shall be briefly presented ${ }^{24}$. It comprises a portrait of a particular company navigating the waves of the changing global economy, and the internal relations between what can be theoretically perceived as its connected life-modes, each of which makes up the preconditions for the others. The company - similar to other companies in the region was visited on a number of occasions from 2014 to 2016, and interviews and life-mode accounts were made with currently and previously employed shop floor workers, managers, and owners, both regarding their working and family life in the local setting. The company and the individuals connected to it epitomize fully the contemporary characteristics of production and work referred to in the introduction. The top management struggles to safeguard the company's survival under heavy international competition and is balancing a double concern of maintaining local control and employment while at the same time satisfying a voracious milieu of investors. The opinion of the latter is recurrently voiced in financial newsletters, where the management is criticized for its inability to prevent "the company [from being led] into a lifethreatening crisis" as one among many criticisms is formulated. The shop floor workers also find themselves in a situation of severe precarity. Former expectations of lifelong employment and a socially stable livelihood are regarded as implausible, and their confidence in efficient support from a weakened trade union system is diminishing. Many stand outside the union or are organized in the liberally grounded yellow unions.

23 JUL NIELSEN, NIELS: Polishness as entrance ticket and barrier to an altered labour market in the Danish construction industry. In: Work Organisation, Labour and Globalisation 9 (2015), issue 1, pp. 63-75. - JUL NIELSEN, NIELS: Migratory Steps. Ukrainians in a Rural Danish Region. In: KUHN, KONRAD/ SONNTAG, KATRIN/ LEIMGRUBER, WALTER (Eds.): Lebenskunst. Erkundungen zu Biographie, Lebenswelt und Erinnerung. FS f. JACQUES PICARD. Köln 2017, pp. 220-231. - JUL NIELSEN, NIELS/ SANDBERG, MARIE: Between social dumping and social protection: The challenge and re-negotiation of creating 'orderly working conditions' among Polish circular migrants in the Copenhagen area, Denmark. Ethnologia Europaea 44 (2014), 1, p. 23-37. - JUL OlSEN/ JUl NIELSEN, 2017 (cf. note 15). - SANDBERG, MARIE: Karol's Kingdom. Ethnologia Europaea (2012), 42, p. 87-93.

24 The analysis is part of the research project Life-modes in the New World Order: The neoculturation of life-modes in a state-system under transformation, funded by the Velux foundation, It continues a further elaboration and development of the life-mode concepts that has been ongoing since the first theoretical life-mode concepts were introduced in the book Det glemte folk. Livsformer og centraldirigering (The Forgotten People: Life-modes and Central Government), published in 1983. 
How can such complexity be grasped without merely clinging to it being arbitrary and beyond structural principles? By means of engaging in a historical account it is possible to lay out the ways in which these distinct, yet interdependent, social groups (here comprehended in life-mode terms) have neoculturated, mirroring patterns that can be met in other regions both in Denmark and internationally. How have they employed life-mode specific means vis-à-vis changing conditions in order to safeguard basic lifemode preferences, be it the managers' control over production and executive capability or the shop floor workers strive for job security and some influence on wage and working conditions?

The company was established in the 1950s with a new kind of heating equipment as the main product. The founder was an innovative entrepreneur, who provided the capital and managed all aspects of the production process himself, and thus can be understood as a traditional productive capitalist in the Marxian sense. Such a small to medium-sized Danish company was typical for the time, employing a workforce of up to a couple of hundred persons. From the beginning the company targeted both national and international markets, and already in 1973 when waves from the global oil crisis hit the company's oil based main product hard, the founder-owner had to allow capital beyond his control to gain considerable influence on running the business; this being severely contradicting what can be understood as his life-mode preferences. The usual local sources of loaning capital withdrew and necessitated involvement with national banks as well as employment of academically educated accountant staff. Thus, on one hand, these measures were taken to protect the founder's interests as a productive capitalist - safeguarding his business - yet at the same time they jeopardized it by allowing for outside control. To prevent the company from being entirely subject to external capital - and from being moved outside the local area in which he saw his family and social life - he subsequently established a family foundation (which established among other things that production should remain in the area), in this way endeavouring to protect fundamental values of his cultural praxis. In analytical terms he tried to protect the company from the temporariness of capitalism by employing counter-measures to safeguard its endurance.

With the later development of the world economy this dialectic between temporariness and endurance increasingly came to mark the running of the business. First, with the opening of the Chinese economy the earnings of the company sky-rocketed when it managed to get access to China's telecom market. The number of employees rose to many hundreds and turnover multiplied. In one sense this stabilised production, yet at the same time - due to the necessity of 'professionalising' the board and attracting investors with venture capital to meet demands of an enlarged scale of production - it exposed the company even more to interests way beyond the control of the ownerfamily, which was still seated in the board and trying to maintain its former influence. Later, during the 2000s, the company experienced in earnest the turmoil of the international markets for production and capital: sales fluctuated due to global competition, this leading to closures or outsourcing of internal business areas. Overall the dependency on large investors, including several capital funds, increased and was even facilitated by the company's listing as a public company. Again, an irresistible logic was at 
work: the measures to consolidate the firm made the future of it increasingly dependent on capital with no local roots. In life-mode terms this development, noticeable in many regions, favours an investor life-mode - dependent on the ability to have no ties to particular companies in order to be able to move investment to the most profitable fields - at the expense of owners with ties and commitment to a particular region.

Also among national states, which otherwise generally have encouraged free flow of capital for its growth potentials, the downside of fluidity can raise concerns. Thus, in Denmark the 'old bourgeoisie' and politicians have occasionally joint forces in order to protect family fortunes, for instance by easing taxation on the transition between generations, as well as by allowing different constructions of foundations, intended to prevent capital from floating freely beyond the borders. Again, in some instances lifemodes and states utilize the extreme temporariness of modern capitalism; in other cases they raise counter-measures to constrain it. From the life-modes' perspective it is a question of what best benefits their necessary conditions, for the states it is a question of continuous sovereignty work in order to maintain a sovereignty domain.

Turning to the employees of the company ${ }^{25}$, a similar paradoxical history is revealed: the measures taken to maintain influence over basic life-mode specific conditions eventually risk jeopardizing these. Throughout the 1960s, 70s and 80s, in line with the prevalent situation in Denmark and most other European countries, minor and major conflicts were frequent in the struggle for improving wage and working conditions, although they never compromised the basic division of employer and employees. With the company's economic ascent during the 1990s this pattern continued but when the company was hit by a major downturn in the 2000s - Chinese capitalists had taken over telecom production and Eastern European entrepreneurs made outsourcing of production attractive - the situation became critical and a grave division among the workers surfaced: between the ones who, as previously, wished to fight against poorer conditions, and another group, which were inclined to join forces with the management to safeguard the company's survival altogether. This second group has more or less refrained from making any demands, eventually risking to let their union-based conflict potential slip out of their hands. The development signifies a typical picture of the contemporary labour market and exemplifies how individuals (here understood in life-mode terms) employ means to maintain the conditions they depend on: in this case people who can in life-mode terms be conceptualized as wage-earners try to prevent the risk of falling victim to global wage-based competition by joining forces with owners to maintain production locally. Thus, in contrast to earlier opinions, an expression such as the following is not unusual among shop floor workers, here from a woman at the assembly line: "it is also my responsibility that we fulfil the objectives. I care

25 For space reasons, a discussion of the group of employees that consists of highly qualified specialists in different kinds of proficiency required to create and incessantly re-create a competitive edge (in life-mode terms understandable as different forms of career-professionals) has been left out. These, in contrast to workers, have been favoured by the global economy with improved conditions for mobility between lucrative career-opportunities, and moreover they are in high course politically due to the increased quest for innovative creativity in the global knowledge economy. 
a lot about that... because I care a lot about the economic stuff and such. You have to optimize continuously... due to the market ... they do that everywhere...".

In these intricate processes the interdependency between life-modes is revealed. To use the above example: The circle of owners at such a company is a mixed group, it might be split between investors merely using their capital to extract a comparably high profit (otherwise moving it to more lucrative fields) and owners who supposedly have an inclination to local commitment (this schism even does not have to be divided between different people but might play out within an individual). When the representatives of 'capital' debates the company's future destiny, it is the latter group of owners that is the target of arguments from the loyal part of the workers. In their fragile attempts to retain their workplace they provide the necessary arguments for the stance, that maintenance of local production, despite the relatively high wages compared to locations abroad, can profit from a loyal and cooperative workforce. Thus, phrased theoretically, in complex processes of neoculturation the means employed by one lifemode to maintain its practice make up the conditions for other life-modes ${ }^{26}$.

In other words, what today appear to be a vanishing of life-mode specific interests in favour of a shared mindset based on common means and ends among all individuals, might be better understood as provisional joining of forces that can safeguard a basic condition for both workers and locally anchored owners: the continuation of the company as such in the area. Should the strategy fail, it is more than likely that previously commonly seen wage-earner sentiments, with an emphasis on the basic division of interests between labour and capital, would surface again and have the wind behind them.

The future development of these fundamental alterations between life-modes and the necessity of developing new concepts to comprehend new forms of production and working culture is high on the research agenda. How do people cope with these altered conditions? Which new forms of enduring practises, with internal connections and conflicting interests, will evolve? Of similar importance is the way in which the transformation of organisation and power relations develops. Traditional labour market organisations are challenged by declining political legitimacy and have lost their former privileged access to policy making ${ }^{27}$. During the end of the $19^{\text {th }}$ century such organisations emerged as a means to oppose the precarity of workers that stood as isolated individuals on the labour market; today they have not managed to prevent a renewed evolution of precariousness. However, their days are probably not numbered, and one way to see future opportunities for changing relations between policy, organisations, production and working lives is to inquire into micro processes of survival for both companies and social practices.

26 Also, the increasingly closer collaboration between shop floor and highly-qualified specialists, whose performance and innovative achievements are key to the company's survival, is a characteristic mark of challenged workplaces of today: by engaging flexibly in processes of production-development, wage-earners become a vital means for the specialist to achieve his or her end - to perform beyond compare - and in return enhances the chance of retaining local achievable jobs, which is crucial for the wage-earners.

27 JUL NiELSEN, 2004 (cf. note 7). - JUL OLSEN/ JUL NIELSEN (cf. note 16). 
